«Системні технології» 2 (133) 2021 «System technologies»

DOI 10.34185/1562-9945-2-133-2021-01

UDC $614.2+574 / 578+004.38$

A.A. Litvinov, M.A. Litvinov

\title{
ON REDESIGN OF UNIFIED CLINICO-STATISTICAL CLASSIFICATION OF DISEASE INFORMATION SYSTEM
}

Annotation. The work is devoted to redesign of Unified Clinico-Statistical Classification of Disease. Text editor-based user interface has been developed and multilayered Architecture was provided. Such modifications made UCSCD management system more flexible, robust and maintainable.

Key words: frame-based representation, clinical diagnosis, classification.

It is even hard to imagine modern medical care without any standards. But the foundation for the standards is not a trivial question: different groups and even medical schools defend their own approaches. But if we think about medical care from system development point of view, we will find a lot of analogical points. We can think about the process of treatment in analogy to the process of tuning or repairing the system. When we try fixing something, the first steps will be devoted to understanding the problem: the nature of the problem and the state of the system required fixing. Knowing the state of the problem can lead us to the proper way of its resolution. In medicine that state called clinical diagnosis can be thought as a formal description of disorder in a compact form which is clear enough to start the treatment. To make that description formal different classifications are used [1-5].

In Ukraine, a group of scientists under the leadership of prof. Bereznitsky Y.S. proposed Unified Clinico-Statistical Classification of Disease (UCSCD) which was rather compact and easy to use in comparison with its foreign analogues [7, 8]. UCSCD is based on standard International Statistical Classification of Diseases and Related Health Problems (10th Revision) [6] and in a simplified way can be thought as its extended version. To make it compact and flexible frame-based knowledge representation model was chosen $[9,10]$.

According to UCSCD model each frame used to represent a set of clinical diagnoses is connected to definite ICD-10 code. As a rule, each frame is composed of several nonterminal slots each of which connected to clinical characteristic (such as Location, Complexity, Phase etc.). An example is shown in Fig.1. The structure of

(C) Litvinov A.A., Litvinov M.A., 2021 


\section{«Системні технології» 2 (133) 2021 «System technologies»}

slot represented as a composition of facets which can be divided into two categories: semantical and syntactical. Semantical facets are as follows: capacity of the slot allowed to describe how many values of the same characteristic can be used simultaneously within clinical diagnosis description; type of characteristic (axis) allowed to describe the class of characteristics. While semantical facets are used to build semantically correct representation allowing to make statistical and analytical processing of clinical diagnosis information, syntactical facets are used for building syntactically correct and comprehensible textual representation of clinical diagnosis (Fig.1).

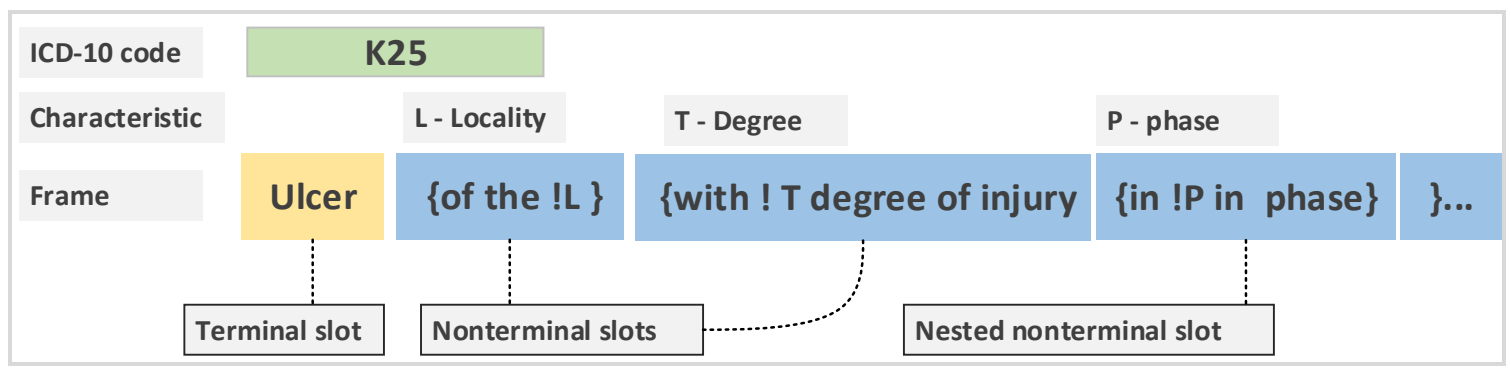

Figure 1 - UCSCD frame structure

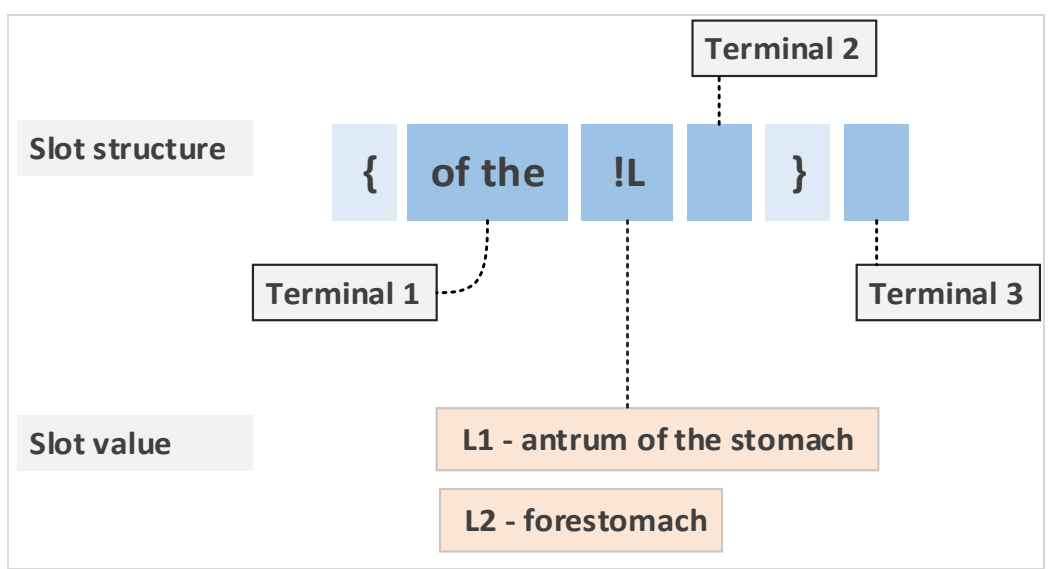

Figure 1 - UCSCD slot structure

Thus, according to the frame structure mentioned above the following code of clinical diagnosis K25 L2T1P1 can be transformed into "Ulcer of the forestomach with moderate degree of injury in exacerbation phase”.

UCSCD is used in two variations: electronic and paper one. Electronic version is based on frame-based knowledge representation model and currently used in two modes: the expert mode allowed to correct and reorganize the frames and the user mode that allows to use it as a source for clinical diagnosis definition, reports etc. Expert shell currently used for editing of frames is shown in Fig. 2-3. 
«Системні технології» 2 (133) 2021 «System technologies»

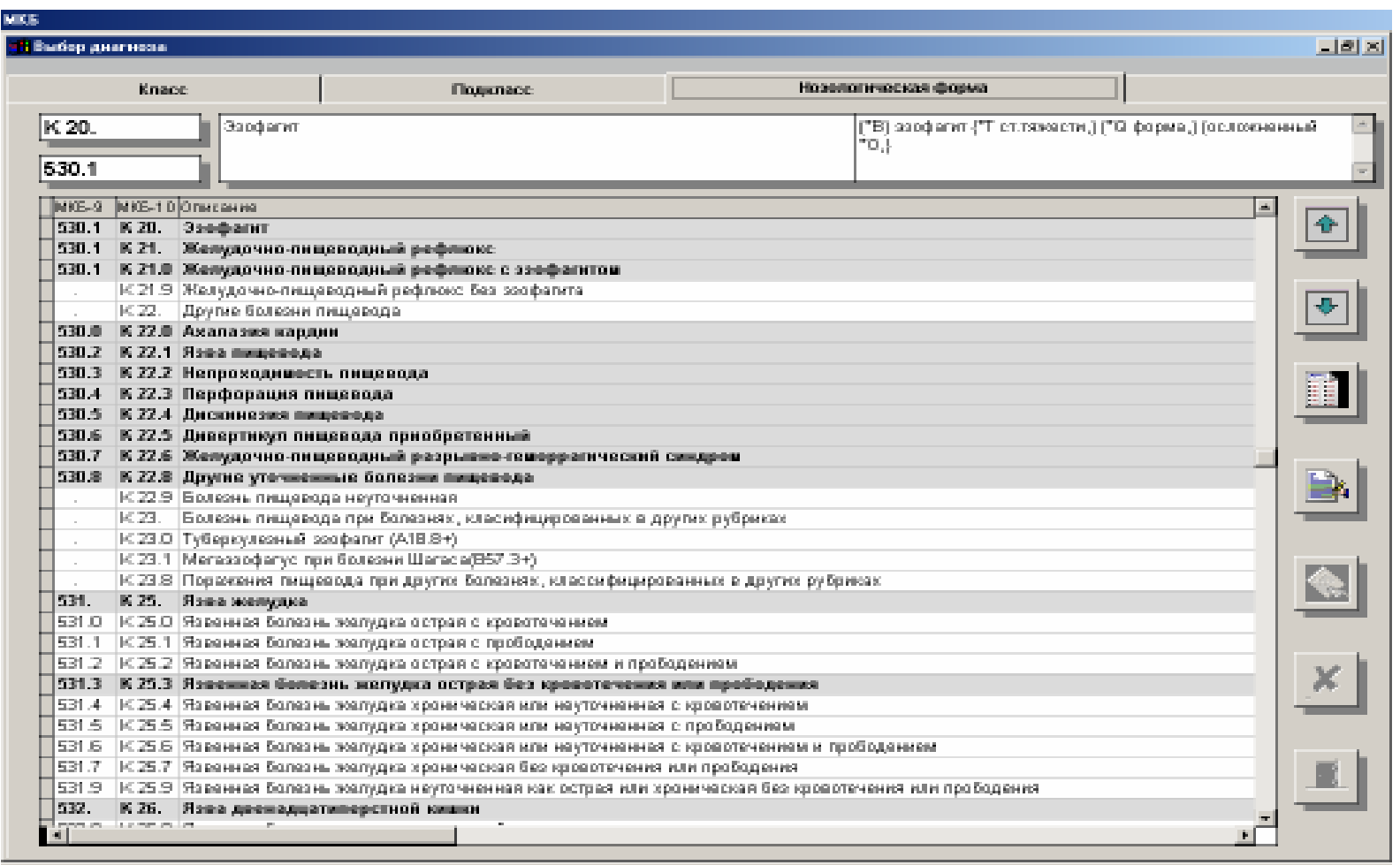

Figure 2 - Unified clinico-statistical classification of disease editor

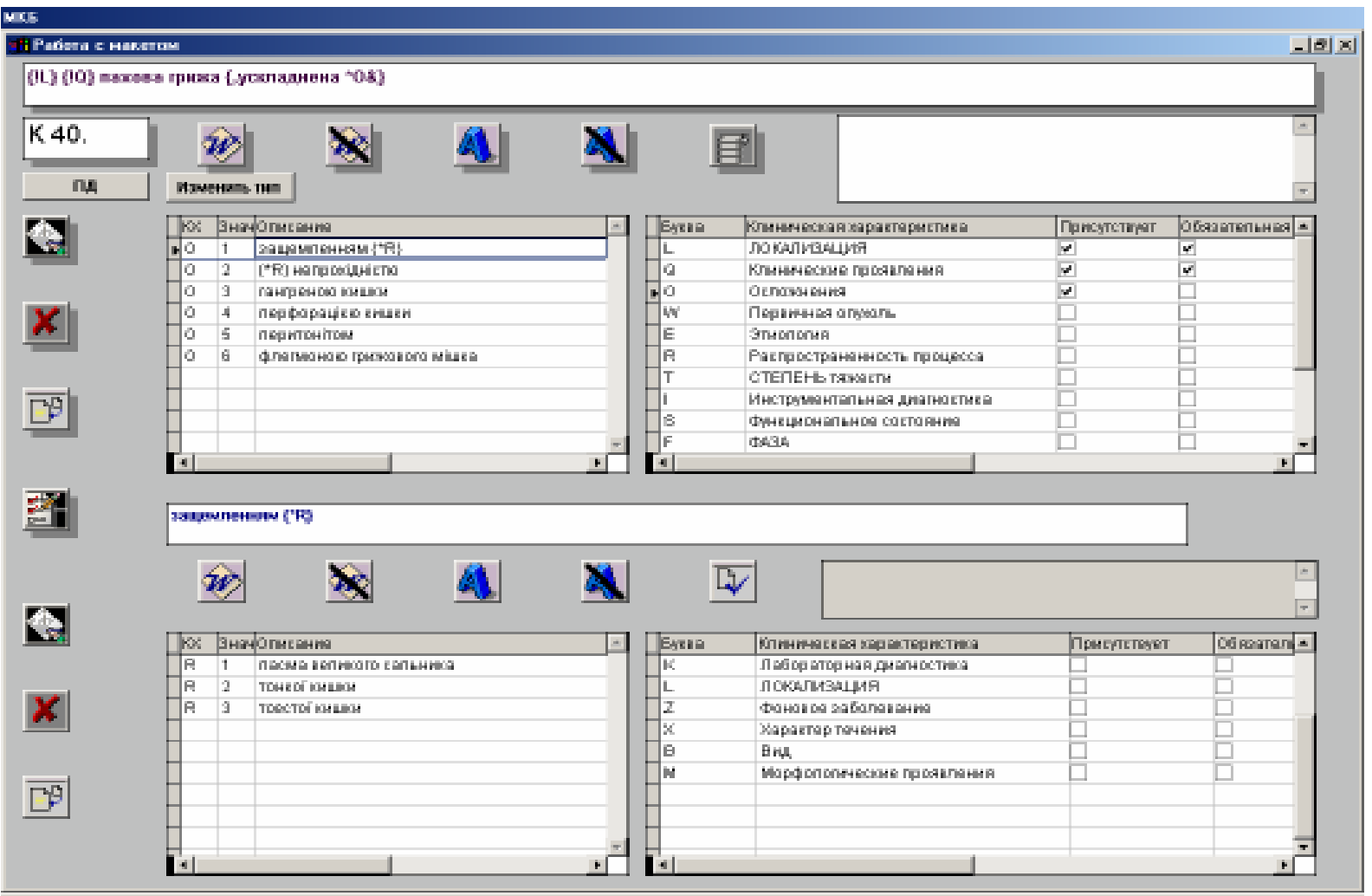

Figure 3 - Unified clinico-statistical classification frame editor 


\section{«Системні технологіï» 2 (133) 2021 «System technologies»}

Task definition. The problem is that in real life there cannot be a lot of experts able to maintain the classification spending a lot of time. Thus, the process of maintenance should be effective enough to be implemented in real organization, considering that the effectiveness is capability of producing a desired result avoiding significant expenses. Firstly, it was suggested to introduce a kind of frame-based classification management language allowed to manage the classification using script files, but it needs a specialist able to write such scripts playing a role of mediator between the expert and classification. First tries showed a number of problems such as translation errors, time delays etc.

Thus, the solution of the problem relates to expert's shell UI reconstruction and adding new functions which were not realized and even could not be realized in its previous version.

Main part. From the start we were focused on two points: escaping misunderstanding and reducing superfluous movements on behalf of the expert; increasing the speed of tasks completion.

Firstly, it was noted that the experts were quite familiar with MS Words Editor. They found it more comfortable to create new structures and modify existed ones than UCSCD editor: he/she frequently copied and pasted pieces of information from one frame into another etc. Of course, direct use of MS Word cannot solve the problem because it does not have necessary checkers able to test the created or modified frames and not connected with the core of the system. Thus, the main direction was to take the idea of MS Words editor as the core concept of expert's shell project.

Secondly, the architecture of the solution was significantly changed: introduced n-layer pattern allowed to switch the application from single expert one computer mode to multi-user client-server one. It can be made by replacing client assembly as it is shown in Fig.4.

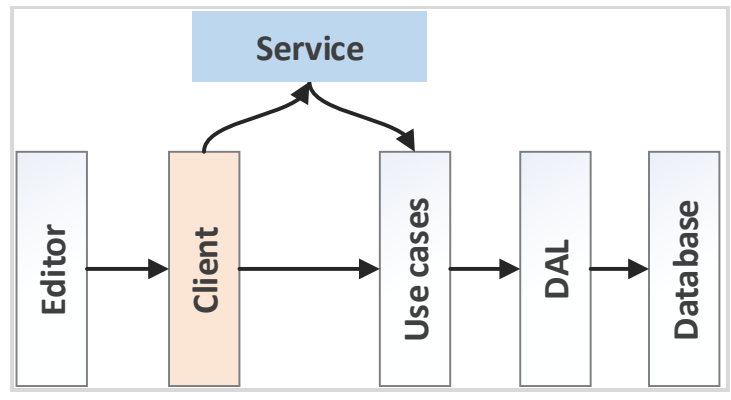

Figure 4 - The architecture of UCSCD

Objective model of UCSCD is represented as tree-based structure shown in Fig.5 which can define nested nonterminal slots and slot values with complex struc6 
«Системні технологіï» 2 (133) 2021 «System technologies»

ture (means the case when slot value is represented by the frame having its own nonterminal slots).

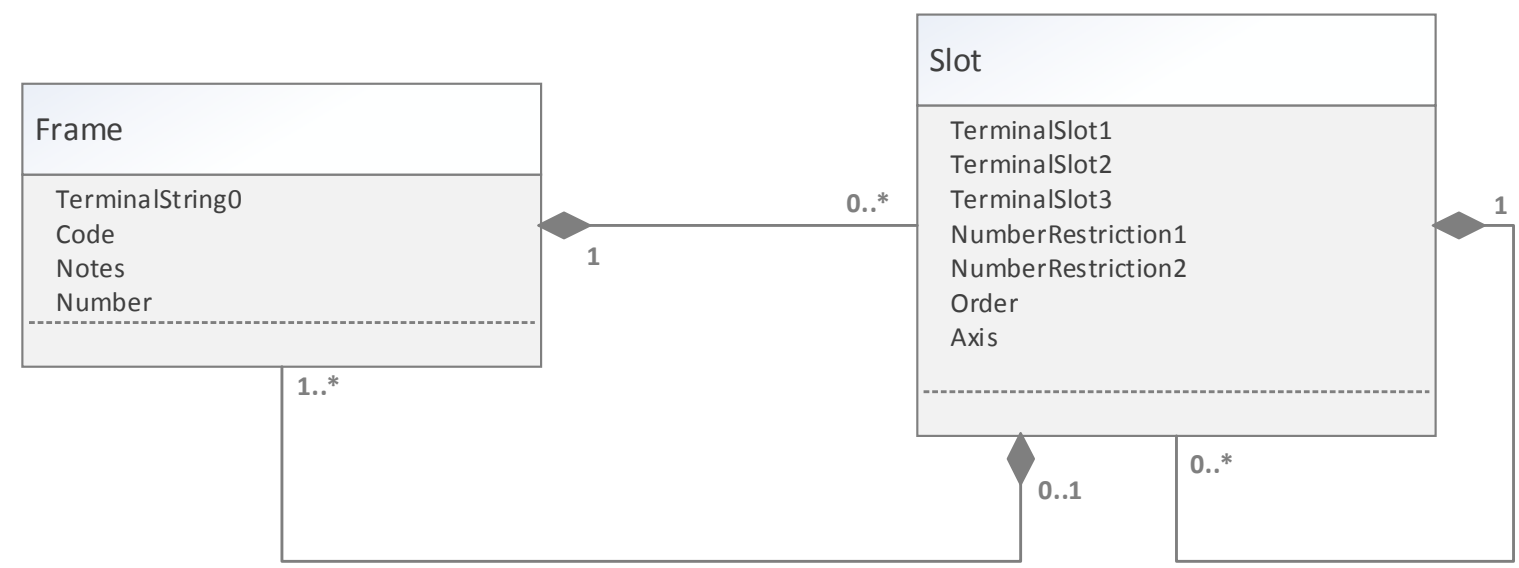

Figure 5 - Objective model of UCSCD domain

In reality, based on the experience of Research Group it is hard to manage frames with more than two levels of hierarchy. It means that slots of complex root frame slot values cannot have complex values (i.e., fames with nonterminal slots). Such restriction also simplifies database structure, which can be represented as 1-n relation of two basic tables: ICD-10 diagnoses table and characteristic table. However, objective model allows to build the structures of any complexity. Thus, in case of changing the database schema, modifications will affect only DAL and Database layer components.

Main functions of expert's shell to be realized were as follows: adding/modifying/removing slots (clinical characteristics) and their values, adding comments, and even switching the languages. All these functions were developed taking in mind the ideas of simplicity and effectiveness of actions and unexperienced user behavior. E.g. to add a new value to the selected slot, user have to just press "=” key and the system analyzes the location of the cursor and defines the slot to which new value should be added, automatically providing its name. To the list of required functions were also added some additional functions which made the process of development more comfortable and effective. They are as follows: rolling back after correction, switching the language. Some actions of inexperienced user can damage the frame and to return it back to the previous point of successful modification or even to initial state can be problematic without "Undo" special function. Thus, we propose to record the history of changes performed by the user and to use "Undo" function based on that history.

Adding the characteristics from other frames to the target one can be done simply by copying of the text from the source frame and pasting it to the target one. 
«Системні технологіï» 2 (133) 2021 «System technologies»

Syntax highlighting and frame checking have also been added. When the user tries to save the results and leave the editor screen, system checks the frame against the rules and informs user in case of errors about the place and the specific of errors occurred. Main window of the editor is shown in Fig.6.

It is notable that to check new added or modified frame its textual description should be converted to the inner representation of "frame-slot" composition and then checked by the Parser component responsible for "text-frame" transformation (Fig.7). Model component responsible for saving modified frame is composed of Client, Service, Business Logic, DAL and Database layers interacted objects. The important point is that for an error occurred while checking the obtained structure, the message which informs end-user about the error should also indicate a line number in the textual frame description which caused that error enabling error block selection (Fig.8).

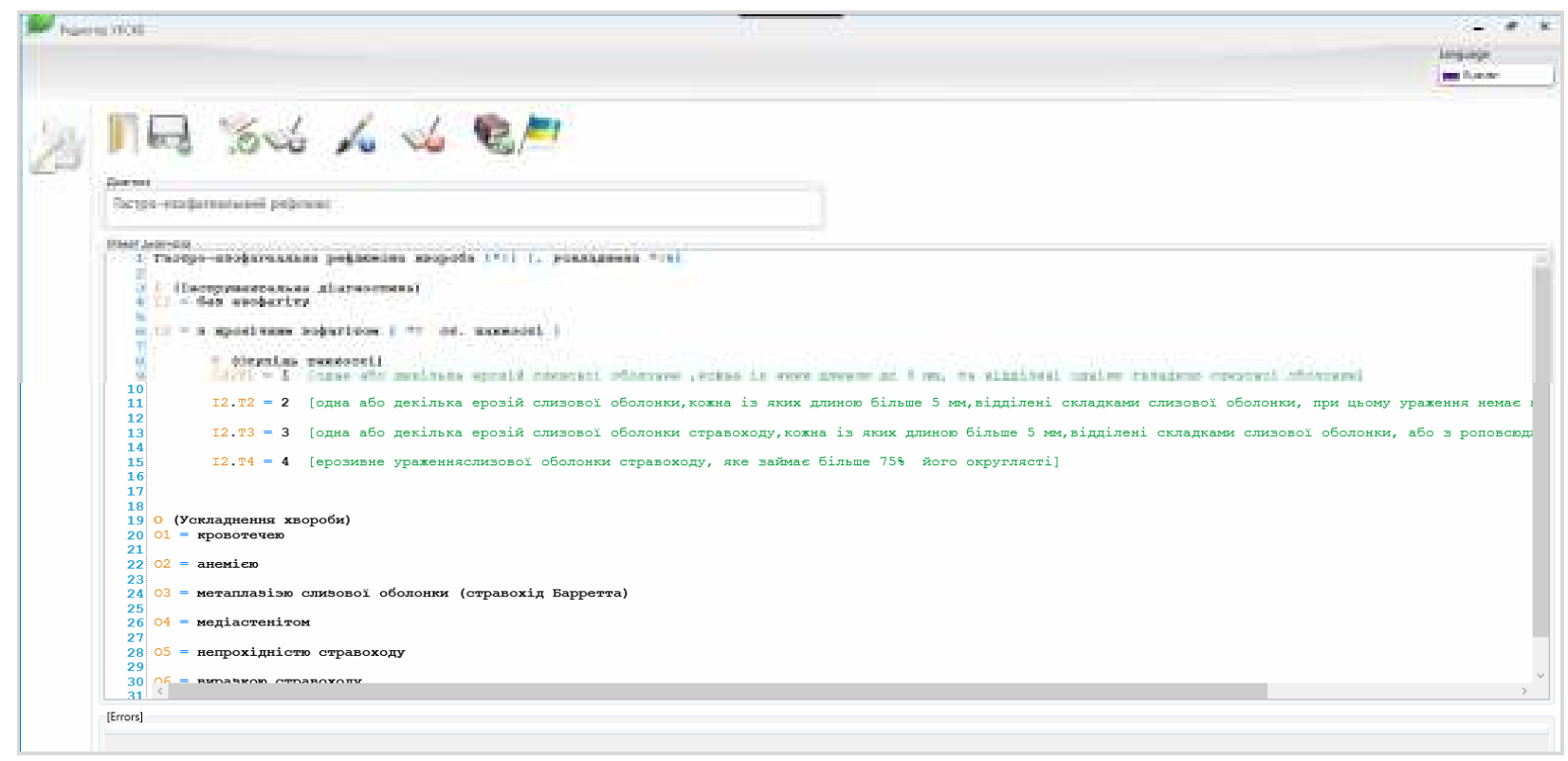

Figure6 - Unified clinico-statistical classification of disease editor

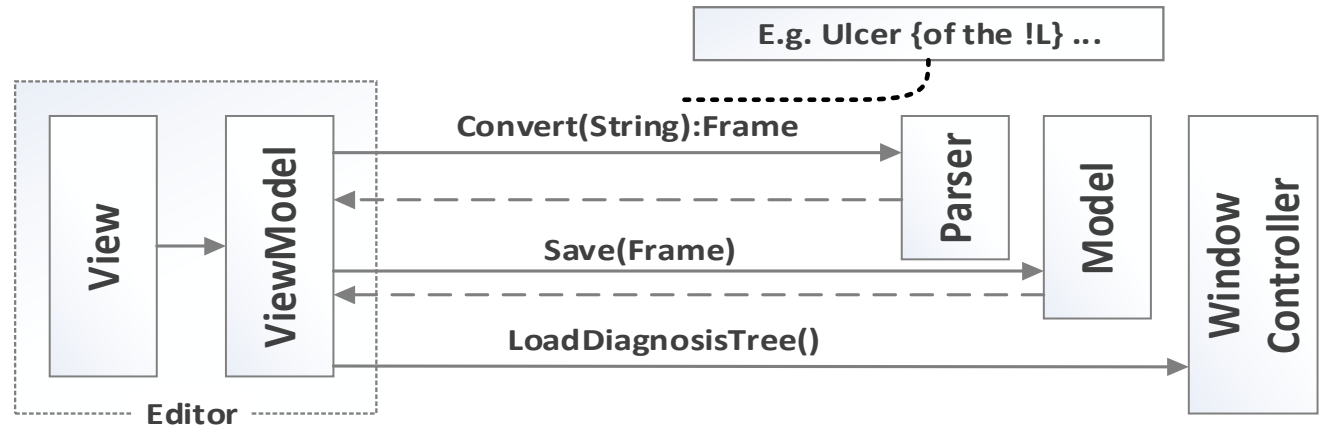

Figure 7 - Transformation of text-based representation into frame component 


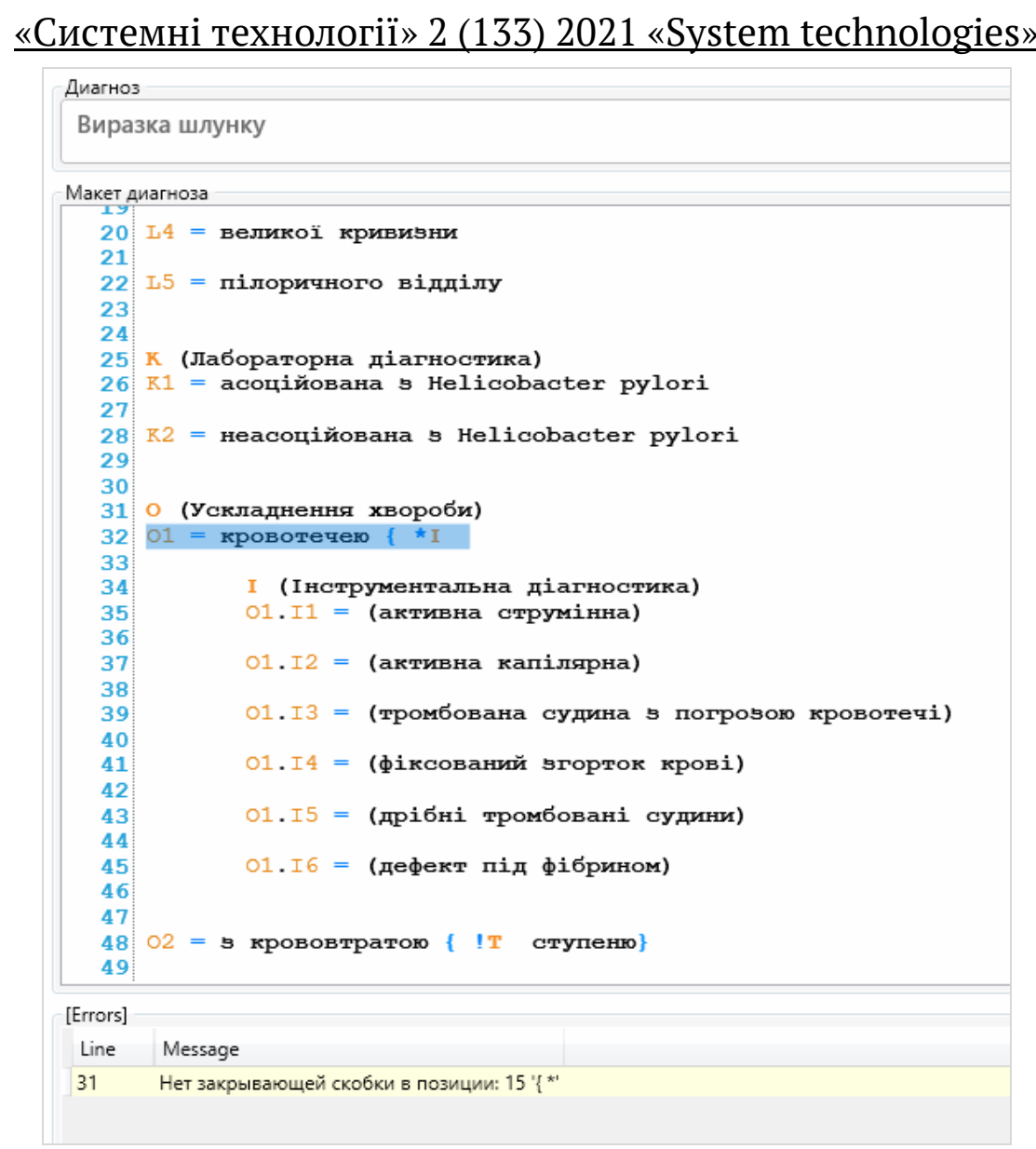

Figure 8 - Frame checking result

In the result, we have got reconstructed UCSCD management system that is more flexible and usable than previous one. First tests have shown the productivity of the expert has doubled.

Summary. Thus, the provided UI is rather flexible than previous one and can be used by the expert more effectively. The main challenge for this version was using textual editor conception as the core idea of the project instead of widespread semantic tree-based variation. The implementation of standard functions was more difficult than in original tree-based version because it was critical to preserve the freedom in actions of end-user, but, in the result, we have got an editor with higher usability, that means higher learnability and memorability, effectiveness and satisfaction. New version of UCSCD is also more robust to modifications noise, such as adding new functions and switching to different database providers and schemes, which significantly improves system maintainability.

\section{REFERENCES}

1. Официальный сайт SNOMED International, http://www.snomed.org.

2. D.J. Rothwell, SNOMED-based knowledge representation, Meth Info Med, 34, 20913, 1995. 


\section{«Системні технології» 2 (133) 2021 «System technologies»}

3. Rothwell D, Coté R. Managing Information with SNOMED: Understanding the model. SCAMC, 1996: 80-3.

4. O’Neil, C Payne, J Read, Read Codes Version 3: A user led terminology, Meth Info Med, 34, 187-92, 1995.

5. Read J, Sanderson H, Drennan Y. Terming, coding and grouping. In: Greenes R, ed. Medinfo 95, 1995: 56-9.

6. ICD-10, International Statistical Classification of Diseases and Related Health Problems - 10th Revision, World Health Organisation, Geneva, (1993), p 314.

7. Литвинов О. А. Інформаційна технологія класифікації клінічних діагнозів на основі семантико-синтаксичної моделі/ О. А. Литвинов.- Київ, 2008.

8. Литвинов О. А. Формалізація клінічного діагнозу і модель електронної класифікації діагнозів для Медичних Інформаційних Систем України./ О. А. Литвинов // Системные технологии.- Выпуск 2(49). - Днепропетровск, 2007. С.46-56.

9. M. Minsky 1975. 'A Framework for Representing Knowledge'. In The Psychology of Computer Vision, ed. P. H. Winston, 211 - 277. New York: McGraw-Hill.

10. Peter D. Karp, The Design Space of Frame Knowledge Representation Systems, Technical Note 520. Artificial Intelligence Center, SRI International, 1992.

Received 03.02.2021. Accepted 05.02.2021.

\section{Перетворення інформаційної системи уніфікованої}

\section{клініко-статистичної класифікації діагнозів}

В роботі розглядається варіант перетворення системи управління уніфікованою клініко-статистичною класифікацією діагнозів.

Уніфікована клініко-статистична класифікація діагнозів - це фреймовий класифікатор, що дозволяє кодувати клінічні діагнози, які використовуються для формування протоколів лікування, глибокого аналізу даних щодо лікування пацієнтів. На протязі десяти років використання накопичилося багато побажань щодо вдосконалення системи управління класифікатором.

Рішення, яке наведено у статті базується на кардинальній переробці інтерфейсу користувача: відходу від класичної деревовидної моделі фреймової структуру, та використання моделі текстового редактора подібному середовищам програмної розробки з введенням функцій, що роблять роботу експерта більш ефективною. Також запропоновано змінити архітектуру додатку з монолітної на багатошарову.

Запропонований варіант дозволяє суттєво спростити управління фреймовою класифікацією діагнозів завдяки зміні підходу до створення інтерфейсу користувача. Розглянуті модифікації архітектури додатку також дозволили зробити систему більш стійкою до змін, полегшити її супровід. 
«Системні технології» 2 (133) 2021 «System technologies»

Преобразование информационной системы унифицированной

клиникостатистичнои классификации диагнозов

В работе рассматривается вариант преобразования системы управления унифицированной клинико-статистической классификации диагнозов.

Унифицированная клинико-статистическая классификация диагнозов - это фреймовый классификатор, позволяет кодировать клинические диагнозы, которые используются для формирования протоколов лечения, глубокого анализа данных по лечению пациентов. На протяжении десяти лет использования накопилось много пожеланий по совершенствованию системы управления классификатору.

Решение, которое приведено в статье базируется на кардинальной переработке интерфейса: ухода от классической древовидной модели фреймовой структуре, и использование модели текстового редактора подобном средам программной разработки с введением функций, делающих работу эксперта более эффективной. Также предложено изменить архитектуру приложения с монолитной на многослойную.

Предложенный вариант позволяет существенно упростить управление фреймовой классификации диагнозов благодаря изменению подхода $к$ созданию интерфейса пользователя. Рассмотрены модификации архитектуры приложения также позволили сделать систему более устойчивой к изменениям, облегчить ее сопровождение.

Литвинов Олександр Анатолійович - кандидат технічних наук, доцент кафедри електронних обчислювальних машин Дніпропетровського національного університету ім. О. Гончара.

Литвинов Михайло Олександрович - студент 4-го курсу кафедри електронних обчислювальних машин Дніпропетровську кого національного університету ім. О. Гончара.

Литвинов Александр Анатольевич - кандидат технических наук, доцент кафедры электронных вычислительных машин Днепропетровске кого национального университета им. О. Гончара.

Литвинов Михаил Александрович - студент 4-ого курса кафедры электронных вычислительных машин Днепропетровске кого национального университета им. О. Гончара.

Litvinov Alexander Anatolievich - candidate of technical sciences, associate Professor of Computer Systems Engineering Department of Oles Honchar Dnipro National University.

Litvinov Mikhail Alexandrovich - 4th year student of the Department of Electronic Computing Machines of Oles Honchar Dnipro National University. 